\title{
鉄の低温脆 性に関する一考察
}

渡辺正紀**蒲地一義**向井喜彦**岡田東一**

\section{Some Consideration on the Low Temperature Brittleness of Iron Crystals*}

By M. Watanabe,** K. Kamachi,** Y. Mukai** and T. Okada**

\begin{abstract}
The plastic behaviour of iron crystals fractured at low temperature have been observed using X-ray as an aid of consideration about "Transition Temperature".

Iron single crystals were made by strain-recrystallization method and Laue photographs were taken before and after the crystals were fractured at low temperature from $-180^{\circ} \mathrm{C}$ to room temperature.

The macroscopic morphology of fractured part of the specimen are shear type and shrink locally, and the direction of incident X-ray beam for Laue photogruphs were normal and parallel to the edge of sheared plane.

The Laue photographs from one shows obvious Central streeks following Debye ring from (110). The latter produces severely deformed spots which have fine structures and Debye ring as well as former. The Debye ring have assymmetlic intense accumulation.

The Laue photographs taken from another direction show strange and fine streaks as photo. IV (a) (c).

We report here the Consideration from these characteristic Laue photographs.
\end{abstract}

\section{1. 緒言}

前年度飞招いて，脆性遷移現象をX線的に考察したので あって、シヤルピー引張衙整試験片の破面执よびその近傍 についてX線扣上び显微鏡による䘽察を行ったが，低温度

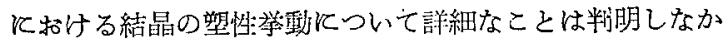
った. この辺の状沅を調べる目的で粗大結晶（単結晶と考 える)を作成してX線的考察した.

粒界括よび隣接結晶の干涉を詳しく観察したい目的を有 したが，結晶の粒界が低温度では脆弱となり，すべて粒界 で破壊が起った為に，この目的は完遂されなかった．しか しながら単結晶を破断した場合のX線像は非常舆味深い 変化を示したので，その結果を報皆する。

\section{2. 実}

験

(i) 試驗片 : -

比較的純度のよい鉄の引拔きの針金を用いて，歪一加熱

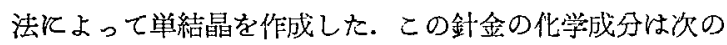
如くである.

Table 1 Chemical Composition of the Specimen Wire

\begin{tabular}{c|c|c|c|c|c|c|c|c}
\hline \hline Component. & $\mathrm{C}$ & $\mathrm{Mn}$ & $\mathrm{Si}$ & $\mathrm{P}$ & $\mathrm{Cr}$ & $\mathrm{Cu}$ & $\mathrm{S}$ & $\mathrm{Fe}$ \\
\hline$\%$ wt. & 0.03 & 0.18 & trace & 0.01 & 0.04 & 0.18 & 0.017 & Rest. \\
\hline
\end{tabular}

原稿受付 昭和 32 年 5 月 2 日（昭和32年度揢接学会春 季学術講演会飞和いて哭表)

** 正員 大阪大学工学部 Member, Faculty of Engineering, Osaka University

作成した単結晶は macro etch を施して確めた後すべ て Laue 写真をとった. そして結晶方位を決定すると共に

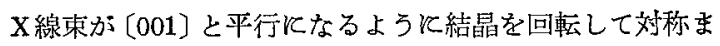
たはこれ近い写真をとった。 これは結晶方位を決定する 外飞 bicrystal または tricrystal でないととを確かめる 目的によってである. 何となれば, macroetchしてす orientation の近い単結晶が Fig. 1 の如く，あるときは， 判別できぬとよ゙しばしばあるからであり，またこのよう な bicrystal ができことが極めて多いからである. bicrystal の場合結晶を goniometer の上で回転すれば standerd photo. Kないような多くの spots が現われるか

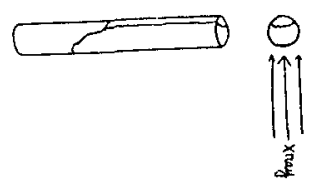

Fig. 1 Bicrystal

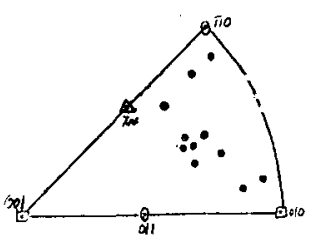

Fig. 2 Orientation of single crystal wires before test

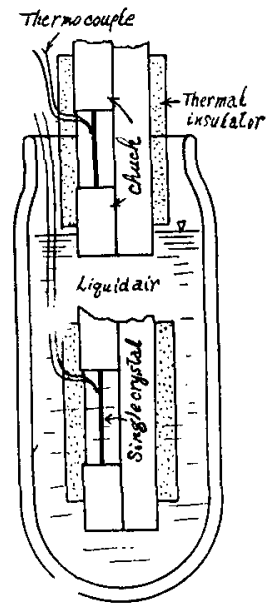

Fig. 3 Apparatus 
ら判定できる．とのようにして決定した単結晶の結晶方位 注 Fig. 2 亿示す如くである.

(ii) 破断 : -

かくの如くして得た単結晶は $-180^{\circ} \mathrm{C}$ から室温までの 範囲内で大体 $20^{\circ} \mathrm{C}$ 宛の温度筬隔で引張り破断した。破断 の要領は Fig. 3 亿示す如くである.すなわち $-180^{\circ} \mathrm{C}$ 破 断は液体空気中で行った． $-160^{\circ} \mathrm{C} \sim-180^{\circ} \mathrm{C}$ 破断は熱絶 緑物で図のように包み，液体空気化数十分浸してから液よ り引上げ，所定温度になった㭙飞破断した．因み飞この㭙 の温度上显の仕方は, $1^{\circ} \mathrm{C}$ 上昇するのに数分か」った.

$-60^{\circ} \mathrm{C} \sim-20^{\circ} \mathrm{C}$ の試験はドライアイス・アルコールを 用い， $-75^{\circ} \mathrm{C}$ 前後に温度を下げ，そのま」の状態で放置 し液温が所定温度になった㭙破断した。

上下のチャックは各温度共すへて液体に浸して試駼片と 同じ温度にしてある。またその熱容量は試駼片に比して充 分大きいものである.

(iii) 破断部の钼察

破断した単結晶は各温度での試験片其破断部分が局部収 縮を起している．この収縮の仕方は之り面と之り方向によ って限定されて Fig. 4 のよう飞なって いる. また顕微鏡で観察したところ引拔 きの際の泚が大きく良好な写真は得られ なかったが，局部収縮部分は $2 \sim 3$ 種の 䚰が起り wavy 状の slip band を示 して招り，deformation band 屯見られ

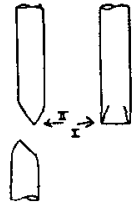

Fig. 4 た. 局部收繀部以外の単結晶部分でも，やはり wavy slip が見られるが defomation band もやはり存在する.

(iv) X線による観祭

破断した綕晶の主として局部收縮部分にX線束を入射し て Laue 写真をとった. 用いたX線は Co 対㓌極を使用 して得た特性線と白色線の混合したものである。簬出条件 は $40 \mathrm{KV}, 10 \mathrm{~mA}, 2.5 \mathrm{hr}$ の露出である. またフイルム, 試 料間の距離社 $30 \mathrm{~mm}$ とし $0.5 \mathrm{~mm} \phi$ の円形平行スリットを 用いた。

また破断部以外の部分にX線を当てた場合も写真をと
り，破断部表面を電解研磨してとり去った場合も写真をと って観察した.

\section{3. 実 䀦 結 果}

前節で述べたらくして得た Laue 写真を次と示す。

Plate I (a), $-180^{\circ} \mathrm{C}$ で破断した試験片に，II の方向より X線を入射したものの写真である.

Plate I (b) $-160^{\circ} \mathrm{C}$

Plate I (c), $-80^{\circ} \mathrm{C}$

Plate I (d), $-40^{\circ} \mathrm{C}$

Plate I (e), $\quad 0^{\circ} \mathrm{C}$

Plate I (f),Room Temp.

で破断したものの，破断部の X 線写真. $-80^{\circ} \mathrm{C}$ と $-40^{\circ} \mathrm{C} \tau$ 破断したものは破断部の極先端 のみが X線束中透された。

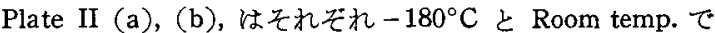
破断した試験片の，正方向からX線束を入射して 得た写真であり,

Plate III (a)は $-140^{\circ} \mathrm{C}$ 破断試料のI の方向からX線 を大射した写真であるが，粒界破断した場合の例 である.

Plate III (b)，(c)，汢乞れぞれ $-120^{\circ} \mathrm{C} て ゙$ 破断した試験 片の破断部の I と II 方向よりの写真であるが表 面より $0.01 \mathrm{~mm}$ 電解研磨して表面をとり去った むのである.

Plate IV (a)，(b)，(c)，はそれぞれI とII以外の方向から X線を入射した場合の Laue 写真であって，(a) $-80^{\circ} \mathrm{C}$, (b) $-160^{\circ} \mathrm{C}$, (c) $-180^{\circ} \mathrm{C}$ の試験片で ある. 極めて鮮明に複雑な streak が現われてい る.

Plate V (a)，(b)，は（a）は破断後飞とった破断部以外 の写真であり，(b)破断以前の orientation 決 定の為の写真である。

Fig. 5〜Fig. 8 はそれぞれ $-180^{\circ} \mathrm{C},-80^{\circ} \mathrm{C},-40^{\circ} \mathrm{C}$, $0^{\circ} \mathrm{C}$ ，飞招いて破断した試験片のIの方向より之った Laue 写真のステレオ投影図である。また Fig. 9，Fig. 10 は $180^{\circ} \mathrm{C}$ 之室温に叔いて破断した試験片の『の方向よりと。 た写真のステレオ投影図である.

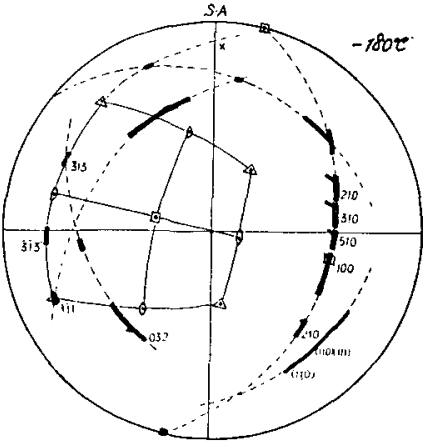

Fig. 5

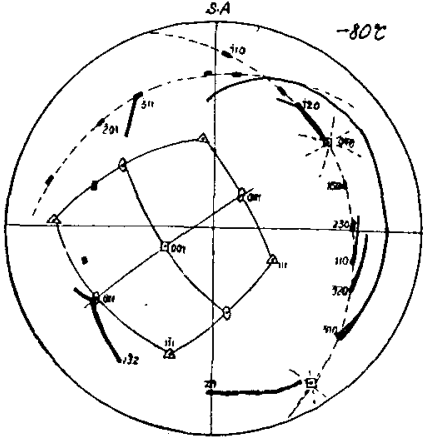

Fig. 6

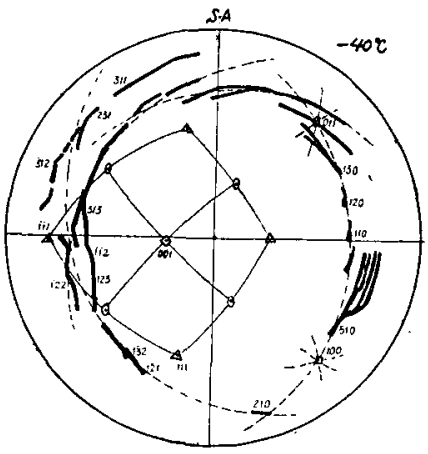

Fig. 7 


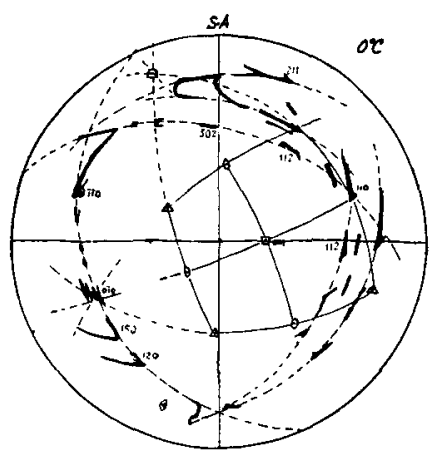

Fig. 8

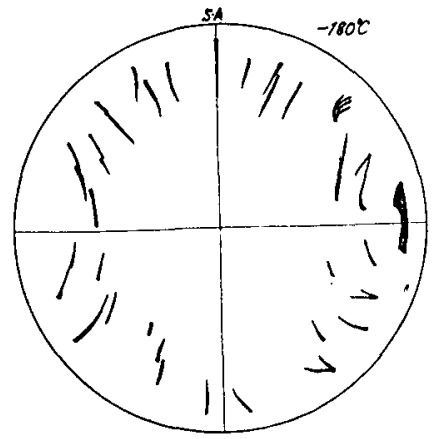

Fig. 9

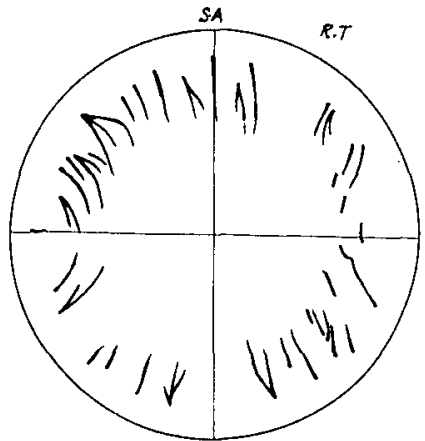

Fig. 10

\section{4. 考察}

(i) 結果の整理

前節に述べた結果をすず整理すれば次のようである.

（a）この種 Laue 写真の特隻として，Iの方向から X 楾を入射した場合 Laue 写真は, spots $の$ 外飞 Debye ringを伴っている.

（b）この spots は甚だしい diffused streakを伴。 ている.

（c）現われた Debye ring は著しい集積点を有し，乙

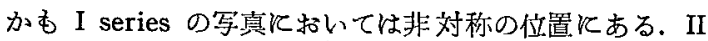
series の写真に呿いてはIK比して強度は弱いが対称に出 ている.

(d) II series では spots はすべて極端な Central streak となっている.

（e） II streaks 括よびI 以外の方向よりとった写真は 特異な streaksを現わしている.

Vogel 呿よび Brick てよると1)，鉄の結晶を加工した 封 Laue の変化は甚たししくいとのへている。この実駼結 果にないても局部収縮を起す寸前までは，極端な変形はな いが局部収縮が始まると極めて著しい如上の变形が起る。

ii）写真の解析

まず個々の場合について考觉るに，I series の写真につ いては,

(a) $-180^{\circ} \mathrm{C}$ 破断試料沉ついては, Laue spots は比 較的鮮明な，しかし，長大な diffused staeak を伴ってい る. streak 中には fine structure が半然と見られ diffu一 se 飞重なって見られる.また streak の末端ね 2 つ分れ ているが，この streak の主体をなす部分は，1つの晶带 隋円に属する spots がのるべきステレオ投影図の大円上K ある. Plate I (a) Fig. $5-160^{\circ} \mathrm{C}$ のものは fine structure は少々認め難い，この場合 spots の main part は大 円上Kあり，その diffuse streak はこの大円とある角度 をなしてこれに交わり，同一の橄点をもつ大円群上にある ようである. $-140^{\circ} \mathrm{C}$ 破断の試料は，gauge 間江繰晶粒界加存在し たため粒界て破断した. $-80^{\circ} \mathrm{C}$ 前後からこれ以下の温度 では粒界の方が脆弱であって，すべて粒界で破壊が起る。 こういう事実は，Vogel \& Brickなども述へている2)。こ の場合の Laue 写真は Photo III (a) の如くである.す なわち結晶は小さい結晶に split 各々は塑性変形を起して いる.

$-80^{\circ} \mathrm{C}$ で破断した場合は，X 線照射部分が破断部の極 先端のみであって，Deby ring は極めて弱く spots のみ が強く出て居り，その diffused streak 注甚しいものであ る. fine structure 恃認㧹る。 $-60^{\circ} \mathrm{C},-40^{\circ} \mathrm{C},-20^{\circ} \mathrm{C}$, $0^{\circ} \mathrm{C}$ 飞扔いて破断した試片の写真は大体に招いて類似した 傾向を示している。すすなるち spots の diffuse 恃著し く面積的な拡がりを呈し，あるいは連続带状となって， fine structure は全々見ることができない，強度は次第に 弱くなっている.

室温の場合岏完全面積的な拡がりのみとなってしま。 て，带状の strerkもボケてくる。これ以上の温度では spots の存在む見分计難くなる.

（b）この写真に伴って現われる Debye ring は単結晶 が破断烸して fragment した表面部分よりの回析によ って起るあのである. このことは Debye ring と Laue spots が同胿に現われることを考祭する為に各温度破断の 試料を電解研磨し，表面より $0.01 \mathrm{~mm}$ 每写真をとった ので明らかとなった。この fragmented part 㯰温度 が高くなる快ど多く深くなる。すなわち $-120^{\circ} \mathrm{C}$ 破䉼の 試料は $0.01 \mathrm{~mm}$ の電解研磨で Debye ring が消失した. また $-60^{\circ} \mathrm{C}$ 試料は $0.04 \mathrm{~mm}$ で, 室温破断試料は $0.05 \mathrm{~mm}$ とり去って消失した. Plate III (b)，(c)，は $-120^{\circ} \mathrm{C}$ 破 断試料を $0.01 \mathrm{~mm}$ etch してとった局部収縮部のI扔よび II の方向からとった'宗真である。この場合は結晶内部が甚 しい変形をして招り，各 spots が判然としない注どであ る. また多数の spots が現われているようであって，2〜 3ケの部分に split したかのようである。

fragment して生じた部分は，Debye ring 上の集積点 
より明らかなように結晶朝が揄った，いわゆる縤維構造を とっているが，集積点が非対标であって，普通の引張り緎 維構造とは異なった特異な texture である.

Polany の式から（110）の垂線が，引張軸となす筩度を 計算すれば Table 2 のようである. 但し，フイルム上， 引張軸と平行な垂直線を基集として(十)は右に( - )は左に 測った角度である。

Table 2

\begin{tabular}{c|c|c|c}
\hline Tested Temp. & $\rho$ & $\begin{array}{c}\text { Angular } \\
\text { deviation }\end{array}$ & Intensity \\
\hline$-180^{\circ}$ & 0 & $\overparen{20^{\circ}}$ & weak \\
& $-18^{\circ}$ & $\overparen{25^{\circ}}$ & ". \\
\hline & $+46^{\circ}$ & $\overparen{40^{\circ}}$ & very strong \\
& $-39^{\circ}$ & $\overparen{30}^{\circ}$ & " \\
& $-72^{\circ}$ & ${\overparen{25^{\circ}}}^{\circ}$ & strong \\
\hline & $+48^{\circ}$ & $\overparen{50^{\circ}}$ & strong \\
Room Temp. & $-69^{\circ}$ & $\overparen{43^{\circ}}$ & very strong \\
& $-80^{\circ}$ & $\overparen{40^{\circ}}$ & " \\
\hline
\end{tabular}

$\rho$ : angle between tensile axis and normal of (110)

次に II series Kついて考觉るに，

（C）現われるべき spotsはすべて著しい Central streak となっている. Plate II (a), (b) $K-180^{\circ} \mathrm{C}$ と室温 破断試料との写真を比輘して示してあるよう飞，破断温度 が高い注ど streaks の数増党，その鋭さを減してくる。 ステレふ投影図を見机ば明らかであるが，この streak は

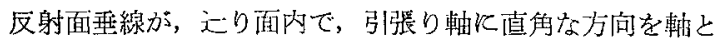

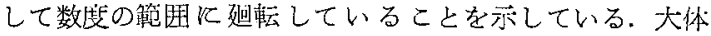
$10^{\circ}$ 前後の節囲炕扰が。ている. Taylor type の回転であ ると考觉られるが，一般飞 asterism の原因といわれてい るすのである。

(d) II series の Debye ring は禁めて弱く，胎んど集 積点のみが現われているようである。しかむ対称である。

(iii) 総 括

以上飞述へたようなととから鉄の結晶を低湿で破断する

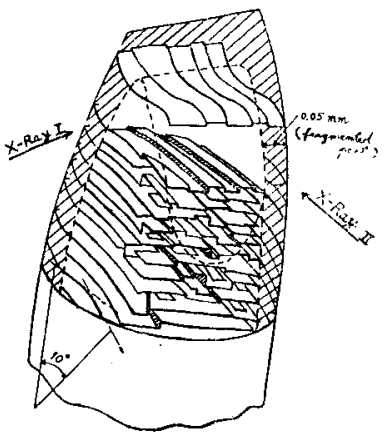

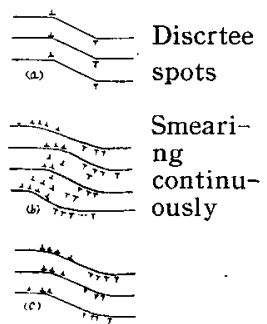

Fig. 12
Fig. 11 |Schemattically view of necking part
場合, その变形の機構が温度と共に变化して行く状態が推 察できる. I とIIの series の写真から推祭される絬鼠の 破壊部の状況は Fig. 11 の如くである。

- $180^{\circ} \mathrm{C}$ K持いて破断による spots の変化状洗は不連 繶な斑点が，玟く尾を引いた元来の spots のボケと重なっ

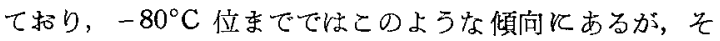
れより高い温度で破断した場合にはこの fine structureは ポケの中に隐れてしまって，連続带状の强度の高いボケと なっている.これ岋らようど塑性変形せしめた結晶を焼鈍 して行く過程と良く似た現象であって，Fig. 12 のように 説明される。すなわち(a)は, spots が polygonization に よって判然とした fine staucture を表わす場合飞相当し， （b）は長くのびたボケに相当する。（c）はこの中間の場合 である. II series の Central streak のステレオ投影図か

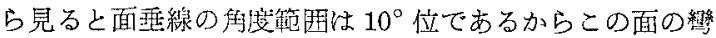
曲の程度は, dislocation density よりほぼ推察することが できる3)。

あう一ついえる垂琵なことは，初めの orientation Kか かわらず，破断後の orientation が注医同様であることと

(ステレオ投影図から.) Debye ring の集槙点の位置が同 様な角度位置们あることから， $180^{\circ} \mathrm{C}$ までの温度籍国内 では，塑性变形はその最後壳で行なわれているのであ。

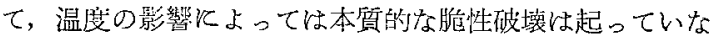
い，むし温度の影響でこの間に脆性破壊が起るとすれば， このようと最終状態なで塑性变形が起り得ないで破域する

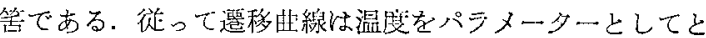

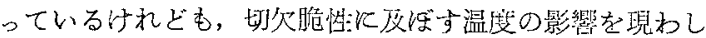

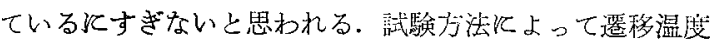
が簧なる所以である。しかしながら温度の低下と共炕司り 難く徒って回転乙難くなることは專弮でおって，さらに低 温度に扣いて実験と行えば究全な脆性破塤が起るかもしれ ない.

\section{5 . 結論}

以上の考察でのベた中に重荘なことが二つ会まれてい る、一つは粒界が低温で推弱であるということと，二つめ は㖶移曲線は町久脆性に攻ほす温度の影留であるというこ とである。

粒界と粒内の张度については諸説あり，equicohesinve

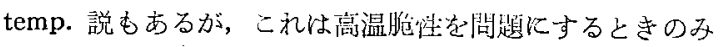

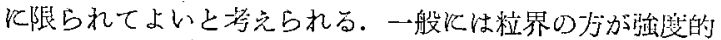

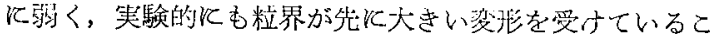

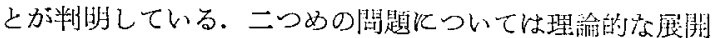
を行う预定であって今後の機会に般告する所存である。

\section{文献}

1) F.L. Vogel, Jr and R. M. Brick. "Jour. of metaIs" May (1953) 700

+ "Progress in metal Physics" vol. 4. 5. 6.j

+ "Imperfection in nealy perfect crystals." 


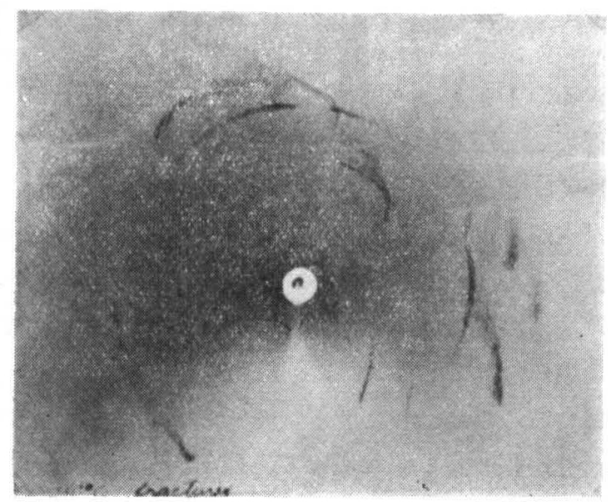

Fiate 1 (a) Fractured at $-1800^{\circ} \mathrm{C}$

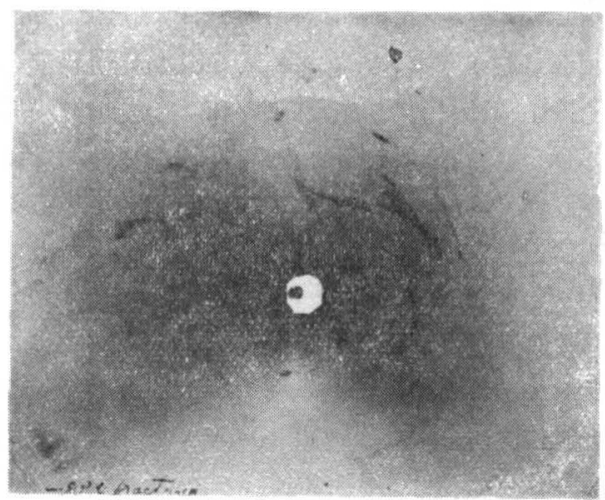

Plate I (c) Fractured at $-80^{\circ} \mathrm{C}$

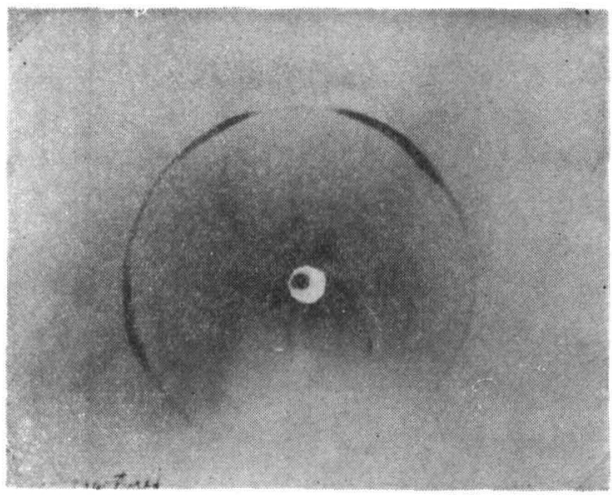

Plate I (e) Fractured $0^{\circ} \mathrm{C}$

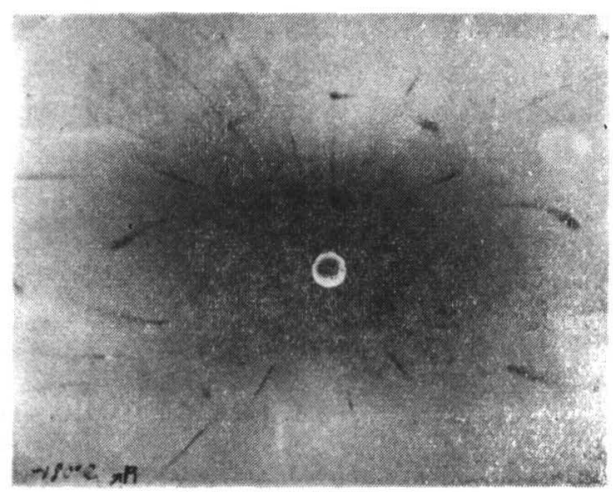

Plate II (a)

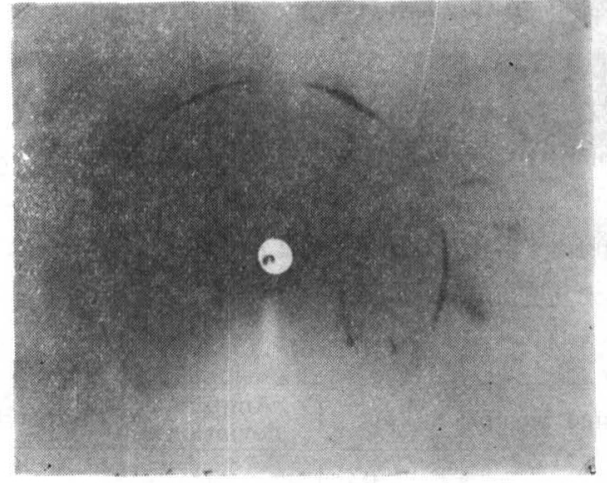

Plate I (b) Fractred at $-160^{\circ} \mathrm{C}$

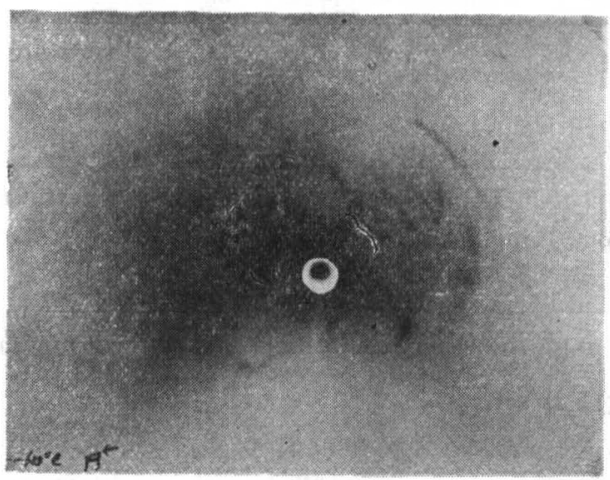

Plate I (d) Fractured at $-40^{\circ} \mathrm{C}$

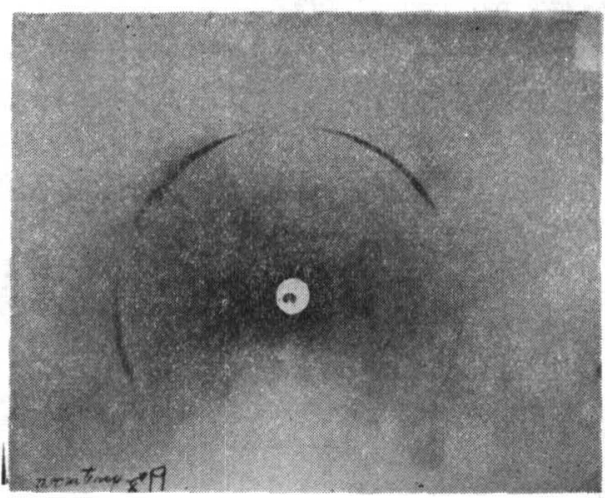

Plate I (f) Fractured at room pempe.

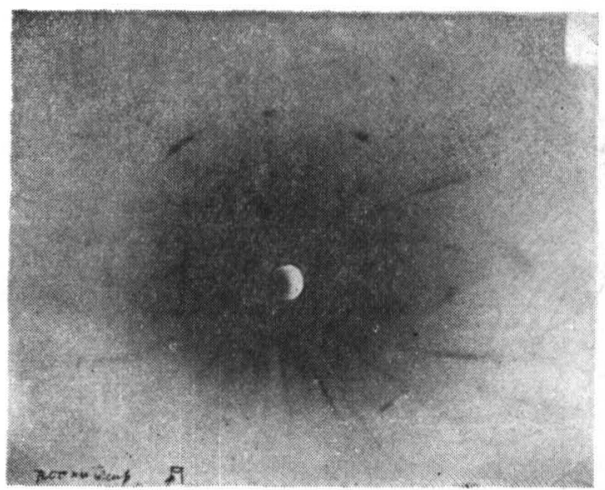

Plate II (b) 


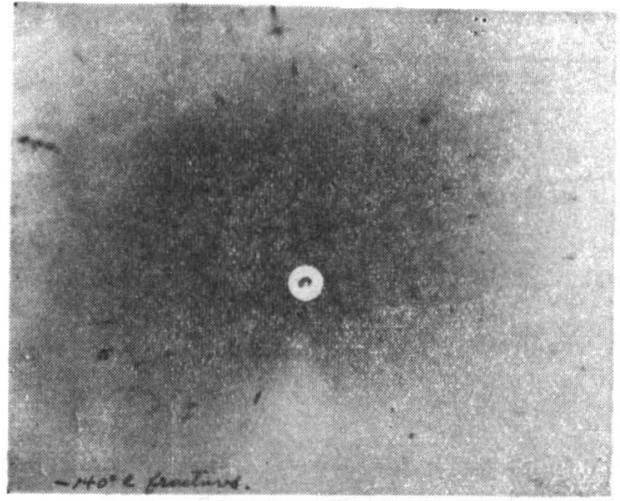

Plate III (a)

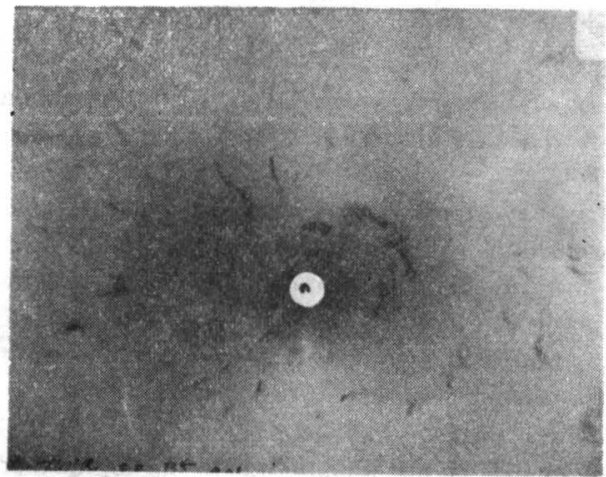

Plate IV (a) $-80^{\circ} \mathrm{C}$

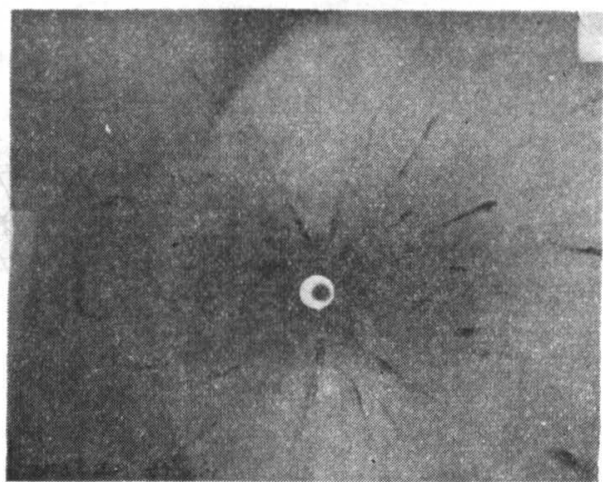

Plate IV (b) $-160^{\circ} \mathrm{C}$

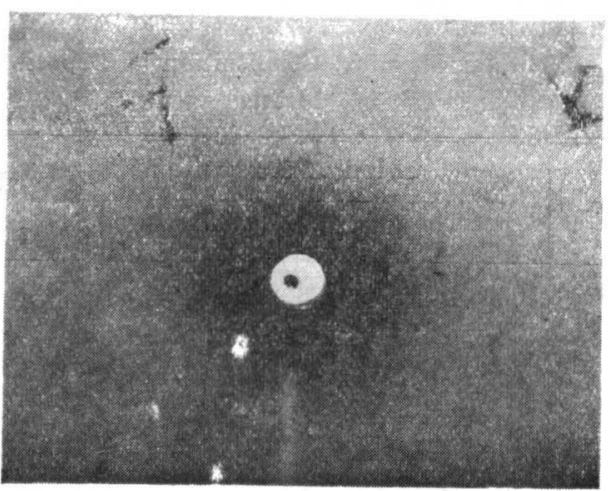

Plate IV (c) $-180^{\circ} \mathrm{C}$

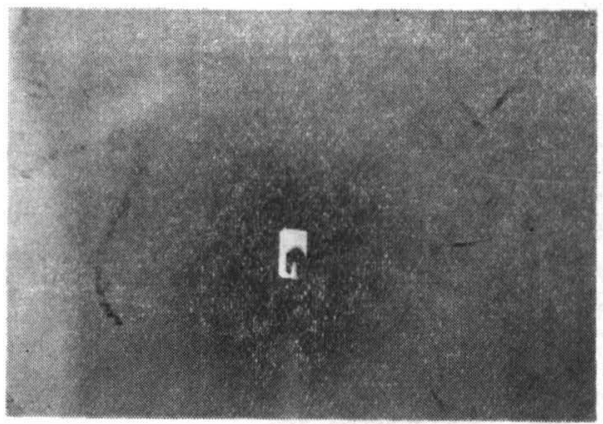

Plate IV (b) $-160^{\circ} \mathrm{C}$

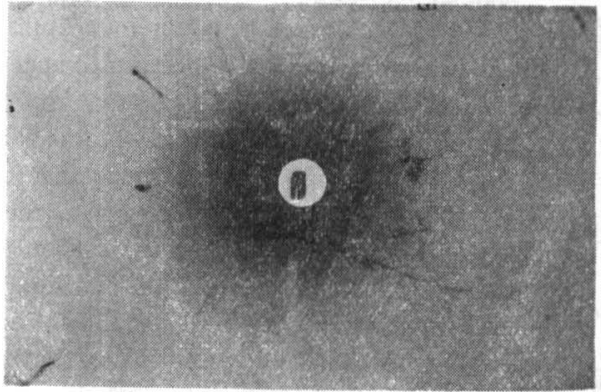

plate IV (c) $-180^{\circ} \mathrm{C}$

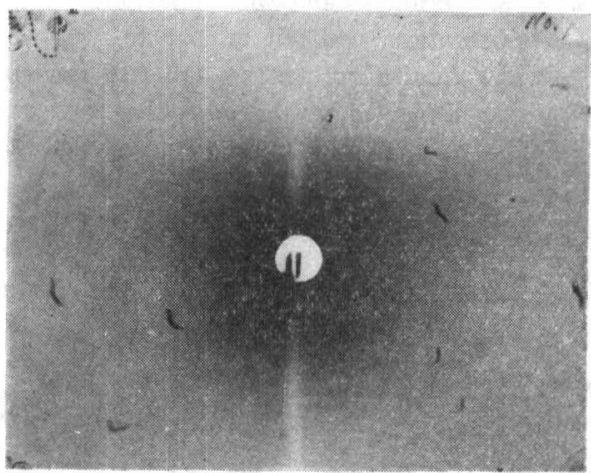

Plate V (a)

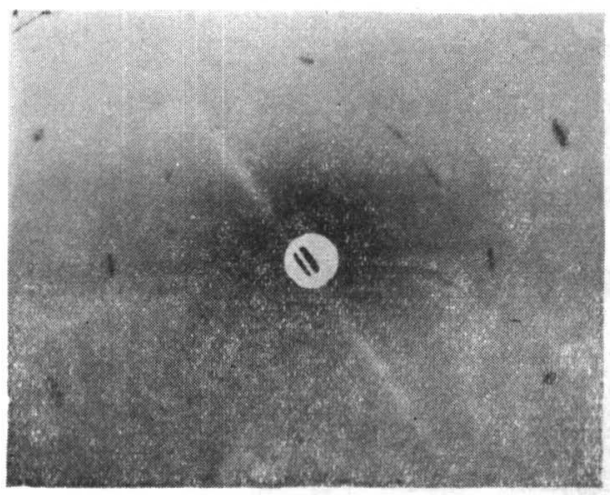

Plate V (b) 